\title{
Q\&A \\ BRITISH CHEMIST BATTLES XENOPHOBIA IN GERMANY
}

\author{
Celina Love talks about her work as an activist in the \\ scientific research hub of Dresden.
}

\section{BY HRISTIO BOYTCHEV}

Why did you decide to do your PhD in Dresden?

It was serendipity. I work in synthetic biology and research the factors that influence enzyme reactions. After I finished my master's degree at the University of Bristol in the United Kingdom, my former supervisor Dora Tang moved to the Max Planck Institute of Molecular Cell Biology and Genetics in Dresden and asked me to join her. I wanted to go abroad, and I knew that Germany has a good quality of life.

What is it like to live there? Dresden is a small city that has a great sense of history and culture. It also has a very international scientific community; only around a quarter of the PhD students are German. What I was surprised about and was not prepared for was the xenophobia that you sometimes see on the streets.

\section{What happens?}

An organization called Pegida has been marching every Monday for four years now, waving German flags and shouting xenophobic slurs. At times, thousands of people attend. It is a very overt form of racism that I find appalling. When they are marching, there is always this feeling of animosity on the streets, and some of my colleagues do not like going into the city. I have not been targeted directly, even though I am also a foreigner, because apparently for them I have the right colour of skin. This hypocrisy is infuriating.

\begin{abstract}
Why did you co-write a letter speaking out against racism? In September 2018, a PhD student from Egypt was verbally abused and physically intimidated on public transport. A person started shouting that the student should go back to the country that she came from, and then the person followed her. It is not the first time something like this has happened. So Peter Swekis, a spokesperson for doctoral candidates from
\end{abstract}

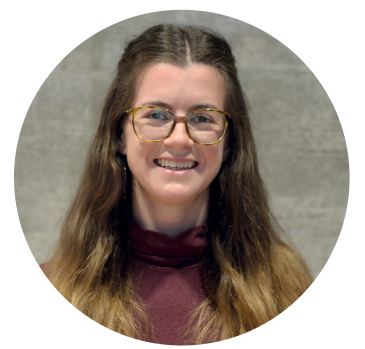

\section{"ONLY AROUND A QUARTER OF THE PHD STUDENTS ARE GERMAN."}

the Max Planck Institute for Chemical Physics of Solids in Dresden, initiated the idea of publishing an open letter condemning this behaviour and advocating the importance of crossborder collaboration for the advancement of scientific research. I joined him, along with five others. Together we represent $550 \mathrm{PhD}$ students from more than 60 countries who are scientifically active in Dresden. We co-wrote a letter and published it on the websites of the institutes. Our goal was to express solidarity with the victims of xenophobic abuse and bring attention to the issue.

The response was positive. The letter was reported on by local media. Most importantly, the person that was assaulted on public transport told me that the letter comforted her. That alone made it worth it. It was the first time I have been directly involved in activism against racism, although I have always cared about promoting equality within science. I am an active member of the Lise Meitner Society, and we work to promote the rights of women and minorities in science and mathematics. I helped to set up a group here in Dresden.

\section{How is Germany's research scene affected by xenophobia?}

Science needs an open and accepting climate for ideas to flourish. Therefore, this kind of incident hurts the reputation of Dresden as a scientific community. I think we need to be more active in providing a countervoice to what is happening. On 21 October 2018, around 13,000 people gathered to protest against Pegida's marches. We tried to organize for the $\mathrm{PhD}$ students to participate. Out of around 100 people, six or seven turned out. There could have been more, but it was a start.

Hristio Boytchev is a journalist in Berlin. 